\title{
THE GASEOUS CONTENT OF THE BLOOD AND THE OUTPUT OF THE HEART IN NORMAL RESTING ADULTS
}

BY C. SIDNEY BURWELL AND G. CANBY ROBINSON

(From The Medical Clinic, Johns Hopkins Hospital)

(Received for publication, July 26, 1924)

I. GASEOUS CONTENT OF THE BLOOD

In a previous paper (Burwell and Robinson, 1924) we have described a respiratory procedure by which a gas mixture is obtained in which both oxygen and carbon dioxide are in equilibrium with those gases in the blood entering the lungs (the mixed venous blood). The equilibration of this gas with blood of the subject allows, therefore, the determination of the oxygen and carbon dioxide content of the mixed venous blood. We used the analytical method of Van Slyke and Stadie. The data thus obtained, together with those obtained by measuring the gas exchange in the lungs, and by counting the pulse, allow the output of the heart per minute and per beat, by a method to be described in the second part of this paper.

Material. In the present paper we wish to report the results of a study of eleven normal resting subjects, all of whom are members of a hospital staff, ranging in age from twenty-five to forty-five years. All observations were made in the morning, after about half an hour's rest in a reclining chair, and at least twelve hours after taking food. As nearly identical conditions as possible were obtained in all determinations.

Gaseous tension of the mixed venous blood. In table 1 are brought together the results of a number of observers. In all instances the principle of using the lungs as an aerotonometer, as suggested by Pflüger has been employed. Loewy and v. Schrötter (1905) measured the tension of oxygen and carbon dioxide in gas withdrawn from an occluded portion of a lung by means of a lung catheter. All other observers have used some modification of the rebreathing method introduced by Plesch (1909). 
The figures of Loewy and v. Schrötter are the average of a number of determinations with fairly wide variations, while the figures of others are either determinations on one subject or show the limits found in small series. Our own findings show a somewhat greater

TABLE 1

Oxygen and carbon dioxide tension of the mixed venous blood

\begin{tabular}{|c|c|c|}
\hline Authors & Oxygen tension & $\mathrm{CO}_{2}$ tension \\
\hline & mm. $\mathrm{Hg}$ & $m m . \mathrm{Hg}$ \\
\hline 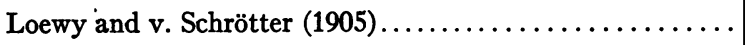 & 37.5 & 42.5 \\
\hline 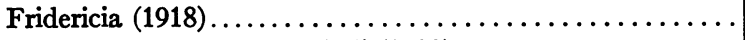 & $35.1-44.5$ & $45.2-46.3$ \\
\hline Barcroft, Roughton and Shoji (1922).............. & 32.6 & 49.5 \\
\hline Douglas and Haldane $(1922) \ldots \ldots \ldots \ldots \ldots \ldots \ldots$ & 46.1 & 44.0 \\
\hline 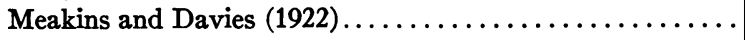 & & $44.4-49.1$ \\
\hline Redfield, Bock and Meakins (1922)............... & $31.0-36.0$ & $45.0-50.0$ \\
\hline Burwell and Robinson $\ldots \ldots \ldots \ldots \ldots \ldots \ldots \ldots \ldots \ldots \ldots$ & $31.6-43.7$ & $41.0-47.0$ \\
\hline
\end{tabular}

TABLE 2

Oxygen and carbon dioxide content of the blood

\begin{tabular}{|c|c|c|c|c|c|c|c|c|c|c|}
\hline \multirow{2}{*}{\multicolumn{2}{|c|}{ Subiect }} & \multicolumn{2}{|c|}{ Arterial blood } & \multicolumn{2}{|c|}{ Mixed venous blood } & \multicolumn{2}{|c|}{ Oxygen utilized } & \multicolumn{2}{|c|}{$\begin{array}{c}\text { Respiratory } \\
\text { quotient }\end{array}$} & \multirow{2}{*}{$\begin{array}{l}\mathrm{pH} \text { of } \\
\text { mixed } \\
\text { venous } \\
\text { blood }\end{array}$} \\
\hline & & $\mathrm{O}_{2}$ & $\mathrm{CO}_{2}$ & $\mathrm{O}_{2}$ & $\mathrm{CO}_{2}$ & & $\begin{array}{l}\text { Of total } \\
\text { oxygen } \\
\text { capacity }\end{array}$ & $\begin{array}{l}\text { From } \\
\text { blood } \\
\text { gases }\end{array}$ & $\begin{array}{c}\text { Gas } \\
\text { exchange }\end{array}$ & \\
\hline & & $\begin{array}{l}\text { vol. } \\
\text { per cent }\end{array}$ & $\begin{array}{l}\text { vol. } \\
\text { per cent }\end{array}$ & $\begin{array}{l}\text { vol. } \\
\text { per cent }\end{array}$ & $\begin{array}{l}\text { vol. } \\
\text { per cent }\end{array}$ & percent & per cent & & & \\
\hline 1 & & 21.76 & 46.01 & 15.23 & 50.70 & 6.53 & 31 & 0.72 & 0.76 & 7.34 \\
\hline 2 & R. & 22.23 & 44.75 & 16.26 & 49.61 & 5.97 & 25 & 0.81 & 0.85 & 7.33 \\
\hline 3 & H. & 22.60 & 45.02 & 17.01 & 49.52 & 5.59 & 23 & 0.80 & 0.81 & 7.32 \\
\hline 4 & F. & 21.80 & & 16.10 & & 5.70 & 24 & & 0.72 & \\
\hline 5 & B. & 23.04 & 46.43 & 18.15 & 49.80 & 4.89 & 21 & 0.69 & 0.71 & \\
\hline 6 & L. & 21.80 & 47.36 & 16.55 & 51.18 & 5.25 & 23 & 0.73 & 0.75 & 7.34 \\
\hline 7 & $\mathrm{G}$ ? & 17.36 & 46.26 & 13.08 & 49.52 & 4.28 & 24 & 0.76 & 0.82 & 7.34 \\
\hline 8 & M. & 22.59 & & 17.14 & & 5.45 & 23 & & 0.76 & \\
\hline 9 & P. & 21.11 & 50.30 & 15.95 & 54.00 & 5.16 & 24 & 0.72 & 0.78 & 7.35 \\
\hline 10 & K. & 21.30 & & 17.21 & & 4.09 & 18 & & 0.71 & \\
\hline & Bu. & 21.00 & 47.29 & 17.86 & 49.63 & 3.14 & 14 & 0.75 & 0.75 & 7.33 \\
\hline
\end{tabular}

variation than previously reported, but our figures are of the same order as those obtained by others. Our own figures, of course, are individual determinations.

The gaseous content of the blood. The oxygen and carbon dioxide content of the blood was determined by the method described in the 
previous paper. Table 2 shows the results of these analyses in the eleven subjects. The oxygen utilized in the passage of the blood through the body is shown in cubic centimeters utilized from each $100 \mathrm{cc}$. of blood and also as the percentage of the total oxygen capacity of the blood. The respiratory quotient has been calculated from the blood gases by dividing the amount of the $\mathrm{CO}_{2}$ lost by $100 \mathrm{cc}$. of blood by the amount of oxygen gained by $100 \mathrm{cc}$. of blood in passing through the lungs. The figures so obtained may be compared with the respiratory quotient calculated from the gas exchange in the lungs, which was determined by the Tissot method during each experiment.' The fairly close agreement that exists may be taken as evidence of the accuracy of the blood gas determinations. A rational respiratory quotient is obtained only when the four determinations for arterial and venous oxygen and carbon dioxide are substantially correct.

The percentage saturation of the blood exposed to the "venous gas mixture" has in general fallen within the limits of previously published dissociation curves. Sufficient variation exists, however, to render the use of so-called standard dissociation curves unsatisfactory.

The $\mathrm{pH}$ figures calculated from the $\mathrm{CO}_{2}$ tension and content agree with those of others for normal subjects, although they are slightly lower than the average determinations of several recent observers. This agreement indicates that no outspoken error occurred in the $\mathrm{CO}_{2}$ analyses of the venous blood, and that as a rule no pronounced acid change occurred during the handling of the blood.

\section{THE OUT-PUT OF THE HEART}

During the past hundred years the problem of the actual volume of the blood expelled by the heart has been attacked frequently by both speculation and experiment. The shrewd guess of Thomas Young (1808) put the output of the heart per beat at an ounce and a half. Such estimations, which were based chiefly upon postmortem measurement of the capacity of the ventricles, were followed by experimental observation upon animals and application of the data so obtained to the calculation of the output of the heart in man. These calculations have resulted in figures so confused and variable that it is quite clear that acceptable determinations must be made upon human subjects. 
Many workers have made observations upon human subjects and various types of data have been the bases of the calculation of the volume of the circulation per minute and per beat in man: (1) the volume flow in the arm, determined by plethysomgraphic methods (Müller, 1909); (2) the measurements of instantaneous x-ray photographs of the heart in systole and diastole (Meek and Eyster, 1923); (3) the amount of some inert gas taken up by the blood in a given time, when the absorption coefficient of the gas for blood is known (Bornstein, 1910; Krogh and Lindhard, (1912); (4) the application of the principle of Fick (Fick, 1870; Loewy u. v. Schrötter, 1905; Plesch, 1909; Douglas and Haldane, 1922). Of these the last two types of data are at present the most acceptable.

It would serve no useful purpose to present again the diverse figures for the circulatory minute volume that have been obtained by different workers using different methods. Not only were the methods widely different but also the conditions of the experiments; the activity, position, and external temperature of the subjects were so varied that the results are in no strict sense comparable. It is worthwhile, however, to point out certain general tendencies in these widely divergent figures. The recorded minute volume varies from 2,800 cc. to $9,000 \mathrm{cc}$. per minute for normal resting adults. There are roughly speaking two groups; in the first are subjects with minute volumes of from 3,000 to 5,000 cc., having usually an output per beat of 45 to $75 \mathrm{cc}$. In the second group are those with minute volumes of 6,500 to $8,500 \mathrm{cc}$., having an output per beat of $100 \mathrm{cc}$. or more. The existence of these two groups of figures has been partly responsible for the development of two contrasting beliefs as to the method of response of the circulation to demand for increased blood supply, a question that will be discussed in a subsequent paper dealing with the response of the circulation to exercise.

The measurements of the output of the heart which we wish to report have been obtained by the application of a method based upon Fick's principle; a principle best described in the words of its originator:

. . . Man bestimme, wie viel Sauerstoff ein Thier während einer gewissen Zeit aus der Luft aufnimmt und wie viel Kohlensäure es abgibt. Man nehme ferner dem Thiere während der Versuchzeit eine Probe arteriellen und eine Probe venösen Blutes. In Beiden ist der Sauerstoffgehalt und der Kohlen- 
säuregehalt zu ermitteln. Die Differenz des Sauerstoffgehaltes ergibt, wie viel Sauerstoff jedes Cubiccentimeter Blut beim Durchgang durch die Lungen aufnimmt, und da man weiss, wie viel Sauerstoff im Ganzen während einer bestimmten Zeit aufgenommen wurde, so kann man berechnen, wie viel Cubiccentimeter Blut während dieser Zeit die Lungen passirten, oder wenn man durch die anzahl der Herzschläge in dieser Zeit dividirt, wie Cubiccentimeter Blut mit jeder Systole des Herzen aufgeworfen wurde. Die entsprechende Rechnung mit den Kohlensäueremengen gibt Bestimmung desselben Werthes, welche die erstere controllirt

As the gases of the blood are now commonly calculated as volumes of gas per $100 \mathrm{cc}$. of blood, a formula conveniently employed is as follows:

$$
\frac{O}{U} \times 100=M
$$

when $O=c c$. of oxygen absorbed per minute.

$U=$ volumes per cent of oxygen utilized.

$M=$ minute output of the heart in cubic centimeter.

In table 3 are shown the oxygen consumed and the carbon dioxide produced per minute, as measured by the Tissot method, the heart rate per minute, the oxygen utilization and the carbon dioxide accumulation in the blood, and the blood flow as calculated from these data. For reasons pointed out in our previous paper, the circulation minute volume calculated from the oxygen figures is considered more reliable than that calculated from the carbon dioxide figures. Therefore, in three experiments in which there was discrepancy between the two and in which there was reason to believe that the fault lay with the carbon dioxide results, only the oxygen figures are included.

It is seen that most of the subjects, under the conditions of the experiment, gave figures for the output of the heart per minute and per beat which agree well with each other. It may be said that the usual minute out-put of the normal resting adult is 3,500 to $4,500 \mathrm{cc}$, and the usual out-put per beat is 60 to $70 \mathrm{cc}$. But there are exceptions and one very satisfactory experiment (Subject Bu.) is a marked exception. This individual had a minute volume of $6,780 \mathrm{cc}$. and an output per beat of $103 \mathrm{cc}$., in spite of the fact that his basal metabolic rate was low rather than high. It is clearly necessary, therefore, to bring evidence as to the constancy or variability of the volume flow 
in a given individual under similar conditions but at different times. Table 4 shows the results of successive studies on two individuals;

TABLE 3

Blood flow in normal resting adults

\begin{tabular}{l|c|c|c|c|c|c|c|c|c}
\hline Subject & $\begin{array}{c}\text { Oxygen } \\
\text { consumed } \\
\text { per } \\
\text { minute }\end{array}$ & $\begin{array}{c}\text { Oxygen } \\
\text { utilization }\end{array}$ & $\begin{array}{c}\text { Minute } \\
\text { output }\end{array}$ & $\begin{array}{c}\text { Heart } \\
\text { rate per } \\
\text { minute }\end{array}$ & $\begin{array}{c}\text { Output } \\
\text { per beat }\end{array}$ & $\begin{array}{c}\text { Carbon } \\
\text { dioxide } \\
\text { produced } \\
\text { per } \\
\text { minute }\end{array}$ & $\begin{array}{c}\text { C.arbon } \\
\text { dioxide } \\
\text { accumu- } \\
\text { lation }\end{array}$ & $\begin{array}{c}\text { Minute } \\
\text { output }\end{array}$ & $\begin{array}{c}\text { Output } \\
\text { per beat }\end{array}$ \\
\hline & $c c$. & $\begin{array}{c}\text { vol. } \\
\text { per cent }\end{array}$ & $c c$. & & $c c$. & $c c$. & $\begin{array}{c}\text { vol. } \\
\text { per cent }\end{array}$ & $c c$. & $c c$. \\
A. & 231 & 6.53 & 3,520 & 54 & 65 & 175 & 4.69 & 3,730 & 69 \\
R. & 236 & 5.97 & 3,950 & 68 & 58 & 200 & 4.86 & 4,120 & 61 \\
H. & 230 & 5.59 & 4,120 & 64 & 64 & 187 & 4.50 & 4,160 & 65 \\
F. & 243 & 5.70 & 4,270 & 64 & 67 & 176 & & & \\
B. & 212 & 4.89 & 4,340 & 64 & 68 & 150 & 3.37 & 4,450 & 70 \\
L. & 235 & 5.25 & 4,480 & 64 & 70 & 176 & 3.82 & 4,610 & 72 \\
G 9 & 192 & 4.28 & 4,490 & 65 & 69 & 156 & 3.26 & 4,790 & 74 \\
M. & 249 & 5.45 & 4,570 & 66 & 69 & 189 & & & \\
P. & 240 & 5.16 & 4,650 & 56 & 83 & 187 & 3.70 & 5,050 & 90 \\
K. & 245 & 4.09 & 6,000 & 68 & 88 & 175 & & & \\
Bu. & 213 & 3.14 & 6,780 & 66 & 103 & 159 & 2.34 & 6,800 & 103 \\
\hline
\end{tabular}

TABLE 4

Successive determinations of two individuals; all under standard resting conditions

\begin{tabular}{|c|c|c|}
\hline Date & Minute output & Output per beat \\
\hline \multicolumn{3}{|l|}{ Subject R } \\
\hline 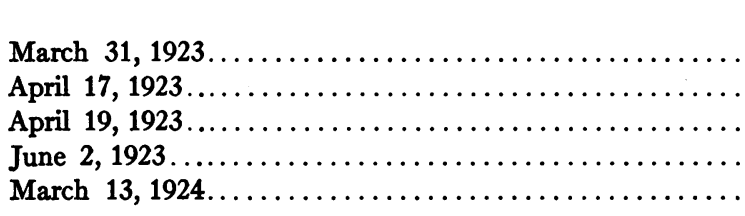 & $\begin{array}{c}c c . \\
3,700 \\
3,940 \\
3,950 \\
3,960 \\
3,760\end{array}$ & $\begin{array}{l}c c . \\
59 \\
60 \\
58 \\
55 \\
57\end{array}$ \\
\hline \multicolumn{3}{|l|}{ Subject B } \\
\hline 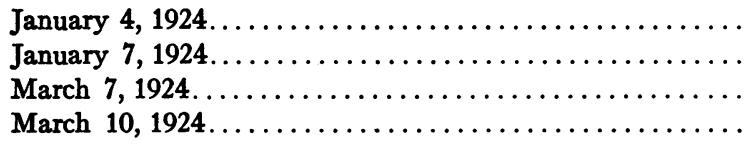 & $\begin{array}{l}6,780 \\
6,260 \\
4,540 \\
5,340\end{array}$ & $\begin{array}{r}103 \\
100 \\
73 \\
83\end{array}$ \\
\hline
\end{tabular}

one of whom had the largest blood flow in table 3. This individual showed wide variation, his minute volume being 6,780 on one occasion and 4,540 on another; with a change in the ouput per beat from 103 
to $73 \mathrm{cc}$. This variation was not associated with a change in pulse rate, metabolic rate, activity, or external temperature. The other subject showed a remarkable constancy of minute volume and output per beat over a period of a year.

Quantitative studies of such a matter as the output of the heart, which is controlled by factors not well understood, are better studied as individual results than as averages. Many determinations of the venous oxygen tension of Subject $\mathrm{Bu}$. indicate that his usual resting blood flow is 6,000 to $7,000 \mathrm{cc}$. although occasionally it may fall

TABLE 5

Blood flow compared with other measurements

\begin{tabular}{|c|c|c|c|c|c|c|c|c|}
\hline \multirow{2}{*}{ Subject } & \multicolumn{4}{|c|}{ Minute output } & \multirow{2}{*}{ 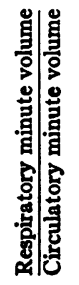 } & \multicolumn{3}{|c|}{ Output per beat } \\
\hline & Total & $\begin{array}{l}\text { Per square } \\
\text { meter } \\
\text { body sur- } \\
\text { face }\end{array}$ & $\begin{array}{c}\text { Per } \\
\text { kilogram } \\
\text { body } \\
\text { weight }\end{array}$ & $\begin{array}{c}\text { Per } \\
100 \text { cc. } \\
\text { oxygen } \\
\text { absorbed }\end{array}$ & & Total & $\begin{array}{c}\text { Per } \\
\text { square } \\
\text { meter } \\
\text { body } \\
\text { surface }\end{array}$ & $\begin{array}{c}\text { Per } \\
\text { kilogram } \\
\text { body } \\
\text { weight }\end{array}$ \\
\hline & $c c$. & $c c$. & cc. & $c c$. & & $c c$. & cc. & $c c$. \\
\hline A. & 3,520 & 1,970 & 53 & 1,525 & 0.90 & 65 & 36 & 1.1 \\
\hline $\mathbf{R}$. & 3,950 & 2,000 & 45 & 1,670 & 0.99 & 58 & 29 & 0.7 \\
\hline H. & 4,120 & 2,190 & 62 & 1,780 & 0.98 & 64 & 36 & 1.0 \\
\hline F. & 4,270 & 2,400 & 64 & 1,750 & 0.82 & 67 & 38 & 1.0 \\
\hline $\mathbf{B}$ & 4,340 & 2,320 & 64 & 2,050 & 0.66 & 68 & 36 & 1.0 \\
\hline L. & 4,480 & 2,500 & 72 & 1,900 & 0.67 & 70 & 39 & 1.1 \\
\hline G ? & 4,490 & 2,750 & 90 & 2,340 & 0.60 & 69 & 42 & 1.4 \\
\hline M. & 4,570 & 2,430 & 67 & 1,830 & 0.90 & 69 & 37 & 1.0 \\
\hline P. & 4,650 & 2,470 & 63 & 1,940 & 0.68 & 83 & 44 & 1.1 \\
\hline K. & 6,000 & 3,470 & 100 & 2,450 & 0.55 & 88 & 51. & 1.5 \\
\hline Bu. & 6,780 & 3,720 & 103 & 3,180 & 0.53 & 103 & 57 & 1.6 \\
\hline
\end{tabular}

much below this. The existence of such wide difference in different healthy people is corroborated by a scrutiny of earlier work. The careful studies of Douglas and Haldane (1922), for example, demonstrated an output per beat of $128 \mathrm{cc}$. in one subject and of $66 \mathrm{cc}$. in another, under similar conditions; and these differences were quite constant in many determinations.

In an effort to study the factors controlling the cardiac output, the minute volume and the output per beat of these normal subjects have been compared with some other measurements. 
In table 5 it is seen that neither the minute output nor output per beat has any exact or noteworthy relation to body weight, to body surface area, or to the volume of oxygen absorbed. The net respiratory minute volume ${ }^{1}$ has not varied directly or inveresly with the circulatory minute volume. There is of course no doubt that the volume of blood flow is a function of metabolic rate, but it is equally clear that there are other factors of potent if subsidiary influence. A study of a series of normal adults such as this, shows that even with favorable and, in a sense, trained subjects - so that basal conditions were well maintained-and with earnest efforts to secure identical surroundings in successive experiments, the minute volume may vary widely in different subjects. Even on the same subject at different times the output of the heart per minute may vary as much as 30 per cent.

\section{COMMENT}

Our figures for the minute output of the heart and the output per beat are smaller than many appearing in the literature. This may be due in part to our.insistence upon rest and fasting. Even so our figures lend support to the view that the output of the heart per beat is not fixed but variable, since an output of 60 to $70 \mathrm{cc}$. per beat is not enough to transport the large volume of oxygen required during strenuous exertion, even at very rapid heart rates. Observations bearing on this problem are reserved for a subsequent paper.

The significance of the variations in volume flow in Subject Bu. is not clear. As the broad physiological viewpoint of Haldane (1922) has emphasized, one object of changes in the volume of blood flow is to maintain the optimum condition of gas pressure in all parts of the body. Changes in blood flow without change in total metabolism suggests the influence of some other factor, or the redistribution of the blood in various parts of the body.

\section{SUMMARY}

In a series of normal adults at complete rest the volume of blood expelled by the heart has varied from 3,500 cc. per minute and 58 cc. per beat to $6,800 \mathrm{cc}$. per minute and $103 \mathrm{cc}$. per beat.

1 The net respiratory minute volume has been calculated from the total amount of air expired per minute with an allowance of $130 \mathrm{cc}$. per respiration for the dead space. 
In one individual, tested repeatedly over a period of one year, the circulatory minute volume varied only from 3,700 to $3,960 \mathrm{cc}$. In a second individual, during a period of two months the circulatory minute volume varied from 6,780 to $4,540 \mathrm{cc}$.

The significance of these findings is discussed. The oxygen and carbondioxide content of the arterial and of the "mixed venous" blood have been determined in the series of eleven adults, and the results are given.

\section{BIBLIOGRAPHY}

Barcroft, J. The Respiratory Functions of the Blood. Cambridge, 1914.

Barcroft, J., Roughton, F. J. W., and Shoji, R. Jour. Physiol., 1921, lv, 371. The Measurement of the Oxygen Content of the Mixed Venous Blood, and of the Volume of Blood Circulating per Minute.

Bornstein, A. S. Arch. f. des. ges. Physiol., 1910, cxxii, 307. Eine Methode zur vergleichenden Messung der Herzschlogvolumens beim Menschen.

Burwell, C. S. and Robinson, G. C. Jour. Clin Invest., 1924, i, 47. A Method for the Determination of the Amount of Oxygen and Carbon Dioxide in the Mixed Venous Blood of Man.

Fick, A. Sitzungsb. der phys.-med. Gesellsch. zu Würzburg., 1870, 16. Ueber die Messung des Blutquantums in den Herzventrikeln.

Fridericia, L. S., Biochem. Zeitsch., 1918, lxxxv, 307. Untersuchungen an Menschen über Sauerstoff und Kohlensauerspannung in Blut der Pulmonalarterie und über Messung des Minute volumens des Herzens.

Haldane, J. S. Respiration New Haven, 1922.

Krogh, A. and Lindhard, J. Skand. Archiv. f. Physiol, 1912, xxvii, 100. Measurements of the Blood Flow Through the Lungs of Man.

Loewy, A. und von Schrötter, H. Zeitsch. f. exp. Path. u. Ther., 1905, i, 197. Untersuchungen über die Blutcirculation beim Menschen.

Meakins, J. and Davies, H. W. Heart, 1922, ix, 191. The Influence of Circulatory Disturbances on the Gaseous Exchange in the Blood. II. A Method of Estimating the Circulation Rate in Man.

Meek, W. J. and Eyster, J. A. E. Am. Jour. Physiol., 1923, lxiii, 400. Cardiac size and out-put in man during rest and moderate exercise.

Müller, A. Deut. Arch. f. Klin. Med., 1909, xcvi, 127, Ueber Schlagvolumen und Kritik der Methode. I. Darstellung und Kritik der Methode.

Plesch, J. Zeitsch. f. exp. Path. u. Ther., 1909, vi, 380. Hämodynamizche Studien.

Redfield, A. C., Bock, A. V. and Meakins, J., Jour. Physiol., 1922, lvii, 76. The Measurement of the Tension of the Oxygen and Carbon Dioxide in the Blood of the Pulmonary Artery in Man.

Young, Thomas. Croonian Lecture on the Functions of the Heart and Arteries. London, 1808. 